\title{
Reversible brachial diplegia in a case treated with cyclosporine
}

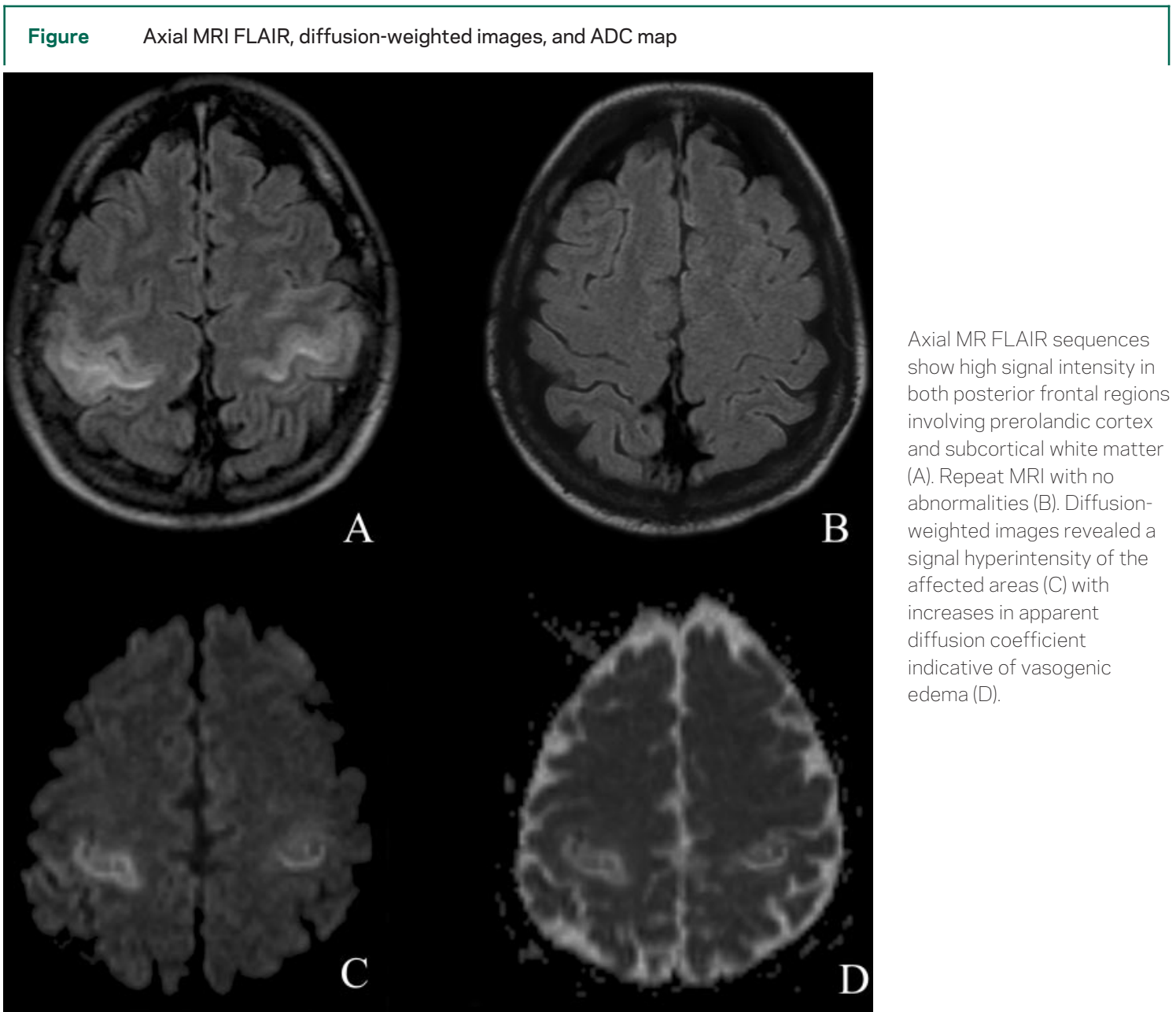

A 32-year-old woman with leukemia underwent allogenic bone marrow transplantation and was subsequently treated with cyclosporine A (CsA) and prednisone. Three weeks after initiation of treatment the patient presented with acute onset of brachial diplegia. NCS MG studies and cervical MRI were negative. Brain MRI revealed increased signal limited to the prerolandic regions, bilaterally (figure, A). CsA treatment was interrupted, and the brachial diplegia improved within a few days. A repeated MRI revealed no abnormalities (figure, B).

CsA induces neurotoxicity in $40 \%$ of patients. ${ }^{1}$ Most of the neurologic side effects of CsA involve the CNS. ${ }^{1}$ However, the involvement limited to the prerolandic areas has not been observed to date.

N. Morelli, MD; M. Mancuso, MD; G. Cafforio, MD; S. Gori, MD; and L. Murri, MD, Pisa, Italy Disclosure: The authors report no conflicts of interest.

Address correspondence and reprint requests to Dr. Nicola Morelli, Department of Neurosciences, Institute of Neurology, Via Roma 67, 56100 Pisa, Italy; n.morelli@inwind.it

\section{REFERENCE}

1. Gijtenbeek JM, van den Bent MJ, Vecht CJ. Cyclosporine neurotoxicity: a review. J Neurol 1999;246:339-346. 


\section{Neurology}

\section{Reversible brachial diplegia in a case treated with cyclosporine}

N. Morelli, M. Mancuso, G. Cafforio, et al.

Neurology 2007;69;220

DOI 10.1212/01.wnl.0000266966.41423.6d

This information is current as of July 9, 2007

\section{Updated Information \&} Services

References

Permissions \& Licensing

Reprints including high resolution figures, can be found at: http://n.neurology.org/content/69/2/220.full

This article cites 1 articles, 0 of which you can access for free at: http://n.neurology.org/content/69/2/220.full\#ref-list-1

Information about reproducing this article in parts (figures,tables) or in its entirety can be found online at:

http://www.neurology.org/about/about_the_journal\#permissions

Information about ordering reprints can be found online: http://n.neurology.org/subscribers/advertise

Neurology ${ }^{\circledR}$ is the official journal of the American Academy of Neurology. Published continuously since 1951, it is now a weekly with 48 issues per year. Copyright . All rights reserved. Print ISSN: 0028-3878. Online ISSN: 1526-632X.

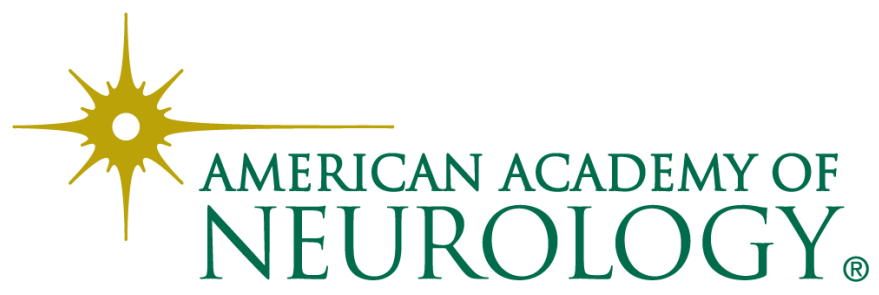

